\title{
Harnessing modern biotechnology for tropical tuber crop improvement: Yam (Dioscorea spp.) molecular breeding
}

\author{
Hodeba D. Mignouna ${ }^{1 *}$, Mathew M. Abang ${ }^{2}$ and Robert Asiedu ${ }^{3}$ \\ ${ }^{1}$ Virginia State University, Agricultural Research Station, Box 9061 Petersburg, VA 23806, USA \\ ${ }^{2}$ International Center for Agricultural Research in the Dry Areas (ICARDA), P.O. Box 5466, Aleppo, Syria and IRAD, \\ Root and Tuber Program, B.P. 2123 Messa, Yaoundé, Cameroon \\ ${ }^{3}$ International Institute of Tropical Agriculture (IITA), Oyo Road, PMB 5320 Ibadan, Nigeria
}

Accepted 20 November 2003

\begin{abstract}
Yams (Dioscorea spp.) constitute a staple food crop for over 100 million people in the humid and subhumid tropics. They are polyploid and vegetatively propagated. The Guinea yams, Dioscorea rotundata and $D$. cayenensis, are the most important yams in West and Central Africa where they are indigenous, while $D$. alata (referred to as water yam) is the most widely distributed species globally. The genetics of yams is least understood among the major staple food crops due to several biological constraints and research neglect. Research to unravel the apparent complexity of the yam genome will have far-reaching implications for genetic improvement of this important tuber crop. Some progress has been made in recent years in germplasm characterization and the development of molecular markers for genome analysis. A genetic linkage map based on amplified fragment length polymorphism (AFLP) markers has been constructed for Guinea and water yams. These linkage maps were used to scan the genome for quantitative trait loci (QTL) associated with genes conferring resistance to Yam Mosaic Virus (YMV) in D. rotundata and anthracnose (Colletotrichum gloeosporioides) in D. alata. In addition, candidate random amplified polymorphic DNA (RAPD) markers associated with major genes controlling resistance to YMV and anthracnose have been identified that could be used for selection and pyramiding of YMV and anthracnose resistance genes in yam improvement. Also, molecular markers such as RAPDs, AFLPs, and microsatellites or simple sequence repeats (SSRs) have been developed for yam genome analysis. An initial c-DNA library has been constructed in order to develop expressed sequence tags (ESTs) for gene discovery and as a source of additional molecular markers. This paper will review the advances made, discuss the implications for yam genetic improvement and germplasm conservation, and outline the direction for future research.
\end{abstract}

Key words: Genetic mapping, genome analysis, molecular breeding, PCR-based markers, QTLs, resistance genes, yam.

\section{INTRODUCTION}

Yam (Dioscorea spp.) is a multi-species, polyploid and vegetatively propagated tuber crop that is cultivated widely in the tropics and subtropics. Over $90 \%$ of world

*Corresponding author. E-mail: jmignoun@vsu.edu. Phone: 1804524 5668. Fax: 1-804 5245186. yam production occurs in the yam belt of West and Central Africa with Nigeria alone accounting for about 68 percent of the world's total (FAO, 2002). Yam production has increased steadily in the last decade, from 18 million metric tonnes in 1990 to recent estimates of over 39 million (FAO, 2002). This increase has been achieved mainly through the use of traditional landraces and can 
be explained by the rapid increase in acreage of yam fields into marginal lands and in non-traditional yam growing areas. There is, therefore, the need to provide farmers with improved varieties that combine high yields with pest and disease resistance, and acceptable tuber quality.

Of the 600 known species of yams, only six are edible or food yams. Dioscorea rotundata and $D$. cayenensis (both known as Guinea yam) are the most popular and economically important yams in West and Central Africa where they are indigenous, while $D$. alata (referred to as water or greater yam) is the most widely distributed species globally. Guinea yams were domesticated in West Africa, while water yam is believed to be a true cultigen that might have been domesticated in Indo-China from Dioscorea hamiltoni and D. persimilis (Barrau, 1965). In West and Central Africa where Guinea yams were domesticated about 7000 years ago, farmers have selected genotypes that best suit their needs, and thus have generated a large number of traditional cultivars.

Genetic improvement programs at IITA (Nigeria) and at the Central Tuber Crops Research Institute (CTCRI, India) have been developing high yielding $D$. alata and $D$. rotundata varieties with pest and disease resistance to meet farmers' requirements. To achieve breeding goals, these institutions and other yam improvement programs in different countries have collected and maintained more than 3,000 germplasm accessions that are being used for yam improvement. There is tremendous genetic variability in yam. Contrary to the situation in other crops where the deployment of improved varieties has led to loss of diversity and a narrowing of the genetic base, some kind of domestication of semi-wild yam species is still on going in west African countries, which continually augments the germplasm diversity (Mignouna and Dansi, 2003). Among the wild yam species most often used for domestication $(D$. abyssinica Hocht.ex Kunth, $D$. praehensilis Benth and $D$. burkilliana J. Miege), $D$. praehensilis is the most important and most exploited in Benin Republic.

Through classical breeding several clones and populations of white and water yams have been developed by IITA in partnership with national programmes in Africa and disseminated for further evaluation and selection under local environmental conditions. Through collaborative evaluation of IITAderived breeding lines with the National Root Crop Research Institute (NRCRI, Umuahia, Nigeria), 3 and 4 varieties of white yam were officially released in Nigeria in 2001 and 2003, respectively. More lines are in the pipeline to be released by root crop programs in other yam producing countries like Benin, Burkina-Faso, Côte d'Ivoire, Ghana, Sierra Leone, and Togo. These varieties have multiple pest and disease resistance, wide adaptability and good organoleptic attributes. Progress in breeding for increased yield, adaptability to marginal environments, improved tuber quality, and pest and disease resistance has, however, been painfully slow due to biological constraints that impede the elucidation of the genetics of important traits in yam. These include a long growth cycle, dioecy, poor to non-flowering, polyploidy, vegetative propagation, a heterozygous genetic background and poor knowledge of the organization of crop diversity.

The long growth cycle of yam, lasting about 8 months or more, exposes the crop to a plethora of pests and diseases among which anthracnose (C. gloeosporioides) and Yam Mosaic Virus disease can be particularly damaging (Thouvenel and Dumont, 1990; Green, 1998). The long period to harvest hinders the flexibility of availability, an important trait for any industrial crop, and considerably lengthens the gestation period for new improved varieties. The vegetatively propagated nature of the crop means that securing clean and healthy planting materials can be an ordeal for poor farmers. Yam is cultivated in widely varying agroecological zones. In Nigeria, for instance, the crop is grown from the southern humid forest to the northern Guinea savanna. Performance of genotypes is very disparate across regions, thereby multiplying breeding goals.

The advent of molecular markers, genome studies, and plant genetic transformation has opened avenues for circumventing breeding obstacles in long growth cycle and heterozygous crops like yam. In spite of these opportunities to build on the success in classical breeding, huge challenges had to be overcome before yam scientists could develop modern technologies towards assisting breeding programs boost yam production and keep up with the ever-increasing demand. To face these challenges, breeding efforts were revived at IITA in the early 1990s, along with a project to develop molecular techniques to unravel the yam genome. This blending of traditional and biotechnological approaches was initiated with funds provided by the Gatsby Charitable Foundation, UK and involved IITA, John Innes Centre, and the Natural Resources Institute, UK.

A better understanding of the available genetic diversity and the breeding potential of specific accessions is important for the choice of parents for use in breeding programs. First, IITA began by developing molecular markers for genetic resource characterization and genetic diversity studies. Yams are polyploid, male and female plants are separate, and both are needed to obtain true botanic seeds. In addition, flowering of male and female plants is difficult to synchronize. The early testing of progenies from hybridization was complicated by yam's slow multiplication rate and the juvenile phase during which it is unreliable to use conventional screens for some economic traits. Molecular markers that are linked to genes controlling these economic traits would be useful in selection at an early stage of the plant's growth, thereby enhancing the speed and efficiency of selection. 
Yam genome mapping was initiated in the mid-1990s. However, the lack of mapping populations and adequate polymorphic molecular markers hampered rapid progress. By the end of 2001 , considerable progress had been made in developing appropriate molecular tools and mapping populations for developing linkage maps of the two most important species, $D$. alata and $D$. rotundata. This review will cover the progress made in molecular marker development, characterization of genetic diversity, linkage mapping, QTL analysis and development of genomic resources.

\section{DEVELOPMENT AND EVALUATION OF MOLECULAR MARKERS}

Breeding and selection of yam cultivars with novel or improved characteristics currently suffers from the fact that traditional cultivars have not been adequately characterized (Asiedu et al., 1998). Considerable linguistic variation exists in the nomenclature of yam cultivars, with each locality having its own unique series of names for the different cultivars (Asemota et al., 1996; Dansi et al., 1999). This seriously hampers the reliable identification of cultivars for germplasm management and improvement. Systems of classification and identification based on morphological characters (Dansi et al., 1998, 1999, 2000a, b), soluble tuber protein profiles (Ikediobi and Igboanusi, 1983) or isozyme patterns (Dansi et al., 2000a; Mignouna et al., 2002c) have been used to characterize yam germplasm. Although effective, morphological criteria present practical drawbacks because the expression of morphological features is often affected by the environment, including the method of cultivation. A major disadvantage of soluble tuber protein profiles is that the profiles may change with the physiological state of the tuber and profiles are usually dependent on tuber storage conditions (Asemota et al., 1992). While isozymes have proven to be valuable tools for genetic discrimination of yam cultivars (Dansi et al., 2000a, Mignouna et al., 2002c), polymorphic isozyme systems are often inadequate for the unequivocal identification of individual cultivars within broad cultivar groups or morphotypes in yam (Dansi et al., 2000a).

The initial effort in yam genomics was devoted to the development of polymorphic DNA markers and assessment of their potential application in yams. Yams are monocots but very distantly related to the grasses; for example, banana and wheat are more closely related to each other than either is to yam. Thus there is no convenient model system for yam genomics. During the course of this project, several attempts were made to exploit heterologous DNA sequences as a source of RFLP markers. This approach had limited success and there was the need to isolate a set of yam gene sequences as a priority for anchoring yam genetic maps.
However, the use of this type of DNA sequence for generating large data sets needed to populate genetic maps is not cost efficient, so the approach of using uncharacterised DNA sequences was adopted as a source of genetic markers. In this regard, random amplified polymorphic DNA (RAPD) (Dansi et al., 2000b) and amplified fragment length polymorphism (AFLP) were the molecular markers of choice (Mignouna et al., 1998).

RAPD and AFLP polymorphism were high among diverse yam species, with AFLP revealing the highest polymorphism. A total of 64 AFLP primer combinations were tested for their potential use in assessment of genetic diversity in white Guinea yam (Mignouna et al., 1998). Over 1000 polymorphic AFLP markers were identified using the 64-primer pairs. Although RAPD markers were adequate for genetic diversity studies (Dansi et al., 2000b), the level of polymorphism detected in mapping populations was low; RAPD was, therefore, not considered a good marker-system for mapping purposes. Contrary to RAPDs, the high level of polymorphism revealed by AFLP markers coupled with their robustness made AFLP a more reliable and reproducible marker-system both for yam genome analysis and mapping purposes. AFLP markers were not only useful for genome mapping but were also very useful for population genetic studies in yam. As progress was being made in yam genomics, microsatellite or simple sequence repeat (SSR) markers were required. Thirty-six microsatellite primers were developed from a genomic library and tested for ability to detect polymorphism in genetic diversity studies of white Guinea yam. The major strength of microsatellites lies in the expected high polymorphism, co-dominant inheritance, high abundance and an even distribution across the genome. Because of the relatively small number of markers developed and the low level of polymorphism detected in mapping populations, microsatellites were not considered a good marker-system for mapping purposes. Additional yam microsatellite markers need to be developed.

The efficiency of AFLP, RAPD and SSR markers for the assessment of genetic relationships, as well as for cultivar identification and discrimination among 45 West and Central African white yam cultivars belonging to 22 morphotype/cultivar groups was investigated. The results showed that each of the three marker-systems could unequivocally identify each cultivar, but that markersystems differed in the mean number of profiles generated per primer (or primer combination) per cultivar, referred to as genotype index $(\mathrm{Gl})$. The order of merit based on this criterion was AFLP $(\mathrm{Gl}=1.0)$, SSR $(\mathrm{Gl}=$ $0.39)$ and RAPD $(G I=0.35)$. Thus AFLP showed the highest efficiency in detecting polymorphism and revealed genetic relationships that most closely reflected morphological classification (Mignouna et al., 2003). 
Mignouna et al. (1998) previously showed that AFLP is a sensitive and robust technique for yam genome fingerprinting. In spite of their robustness, technical and financial burdens associated with AFLP and SSRs limit their availability to laboratories in developing countries where most of the research on yam is conducted. Thus cost considerations may make RAPD the method of choice for laboratories with rather limited resources.

\section{PROGRESS IN MOLECULAR GENETIC ANALYSIS OF THE YAM GENOME}

The ability to use molecular marker biotechnology to exploit information at the gene level, based on genome mapping and marker-assisted genetic analysis and breeding, now offers a practical solution to many of the intractable problems in yam breeding. Molecular genetic maps and marker-aided analysis of complex traits can be used to elucidate the genetic control of yield potential and tuber quality, and locate genes of pest and disease resistance, nutrient use efficiency, and flowering. For these reasons, a concerted effort to map the yam genome and dissect the inheritance of complex traits was initiated at IITA. The marker type chosen was AFLP, and an early goal was to make this methodology available at IITA, where the procedure has a general applicability, including germplasm characterization, genetic mapping and marker-aided selection.

\section{Segregating populations and inheritance of disease resistance}

It was anticipated that cultivated yams would have their origin from a cross between genetically distinct individuals, so the alleles derived from each parent may be different. Many cultivated yams are tetraploid $(2 n=4 x$ $=40$ ), so each genetic locus is expected to be represented by two homeologous pairs. Thus for any gene a given individual may have up to four alleles. One general approach to mapping plants of this type is to examine the genotypes of selfed progeny; however, this is not feasible for dioecious yams, so the approach taken was to generate multiple $F_{1}$ individuals derived from crosses between the same parents. $F_{1}$ mapping populations of $D$. alata and $D$. rotundata were subjected to in vitro micropropagation based on techniques developed by $\mathrm{Ng}$ (1992). D. rotundata populations segregated components of resistance to Yam Mosaic Virus, genus Potyvirus (Mignouna et al., 2001b), while the $D$. alata populations segregated for yam anthracnose disease resistance (Mignouna et al., 2001a).

Yam Mosaic Virus is a major limiting factor for stable production of yams, and $D$. rotundata is particularly susceptible to the virus (Thouvenel and Dumont, 1990).
Genetic resistance is the only economically viable method of control. A study of the genetic control of YMV resistance in three $D$. rotundata cultivars to a Nigerian isolate of YMV showed that resistance is manifested differentially as the action of a single dominant gene in simplex condition or a major recessive gene in duplex condition (Mignouna et al., 2001b). The dominant locus that contributes to YMV resistance was tentatively named Ymv-1, until tests of allelism are conducted. The availability of genotypic diversity for YMV resistance is extremely interesting to breeding programs because both genes could be pyramided in the same genetic background or used separately against infection by this virus. Anthracnose disease, caused by Colletotrichum gloeosporioides (Abang et al., 2002), is a major constraint to the production of yam worldwide (Winch et al., 1984; McDonald et al., 1998), with $D$. alata, the most widely distributed species, being particularly susceptible to the disease. Resistant yam cultivars could form the basis of sustainable management strategies for anthracnose. Initial genetic inheritance studies showed that resistance to yam anthracnose in $D$. alata is dominantly but quantitatively inherited (Mignouna et al., 2001a). A single major dominant locus controlling resistance in the breeding line TDa 95/00328 was tentatively designated $D c g-1$, until allelism is investigated. The efficiency and effectiveness of breeding for YMV and anthracnose resistance will be greatly improved by marker-assisted selection based on genetic mapping of major genes controlling the resistance.

\section{Genetic mapping and QTL analyses}

Chromosome pairing in tetraploids can occur such that only homologues pair, or such that any two homeologues may pair. These two types of pairing have very different consequences for segregation patterns so that these plants may, in the extreme, exhibit either diploid or tetraploid genetics. Intermediate types of behaviour may also occur. Thus it was important to establish which type of segregation was being observed in the cultivated yams. Genes controlling important traits such as yield, tuber quality, and pest and disease resistance are usually distributed among several quantitative trait loci (QTLs), which may not be linked, thus making these traits difficult to manipulate using conventional breeding methods. The recessive nature of Yam Mosaic Virus resistance in some $D$. rotundata genotypes means that such resistance cannot be easily tracked at the phenotypic level, demanding refined diagnostic procedures such as molecular mapping for detailed genetic localization of specific genes (Mignouna et al., 2001b). Screening by molecular markers linked to QTLs has the advantage of selecting pairs of parents with genes at different QTLs for the same trait (Solomon-Blackburn and Barker, 2001). 
Using traditional cultivars/landraces and breeding lines, researchers initiated experiments to identify quantitative trait loci (QTL) affecting these traits.

A preliminary study on genetic mapping of $D$. rotundata revealed diploid segregation patterns for alleles at RAPD, isozyme and a few AFLP marker loci (Mignouna and Asiedu, 1999). In that study, the detection and estimation of linkage was carried out according to the pseudo test cross method using single dose markers (SDM) because the genome constitution of yam was not known (alloversus auto-polyploid). This approach resulted in a rather limited linkage map comprising 4 linkage groups made of 12 markers each for the male and female parents (Mignouna and Asiedu, 1999), mainly because only a small proportion of RAPD and AFLP markers that were polymorphic between the two parents fit the condition of SDM. This situation explains the use of a more polymorphic source of markers such as AFLP.

Genetic mapping using AFLP led to the construction of the first, separate, comprehensive, molecular linkage maps of $D$. rotundata and $D$. alata. The $D$. rotundata map was based on 341 co-dominantly scored AFLP markers segregating in an intraspecific $F_{1}$ cross. Separate maternal and paternal linkage maps were constructed, comprising 12 and 13 linkage groups, respectively. The mapping population was produced by crossing a landrace TDr 93-1 as female parent and a breeder's line TDr $87 / 00211$ as the male parent. The markers segregated like a diploid cross-pollinator population, suggesting that the $D$. rotundata genome is an allo-tetraploid $(2 n=4 x=40)$. However, the possibility that occasional homeologous exchanges may occur cannot be ruled out. Three QTLs with effect on resistance to YMV were identified on the maternal linkage map, while one QTL for YMV was detected on the paternal linkage map (Mignouna et al., 2002e). These results showed that both parents contributed to the phenotypic resistance of the progeny.

Similarly, a genetic linkage map of the tetraploid water yam (Dioscorea alata) genome was constructed based on 469 co-dominantly scored AFLP markers segregating in an intraspecific $F_{1}$ cross. The $F_{1}$ was obtained by crossing two improved breeding lines, TDa 95/00328 as female parent and TDa 87/01091 as the male parent. The 469 markers were mapped on 20 linkage groups with a total map length of $1,233 \mathrm{cM}$. Again, the markers segregated as in a diploid cross-pollinator population, suggesting that the water yam genome is allo-tetraploid $(2 n=4 x=40)$. One QTL located on linkage group 2 was found to be associated with anthracnose resistance, explaining $10 \%$ of the total phenotypic variance (Mignouna et al., 2002d). Conservative estimates put the genome coverage of the $D$. rotundata and $D$. alata maps at $56 \%$ and $65 \%$, respectively. There are several reasons why the maps may not give complete coverage. The most obvious is that the two parents may have some common ancestry so that segments of the linkage maps may be devoid of polymorphism and thus cannot be identified in genetic analysis.

One approach to trying to gain some insight on this issue would be to attempt to align the $D$. alata and $D$. rotundata maps. This would give us additional confidence in the general map structures and enable the development of suitable markers for genomic surveys of other populations. An attempt was made to derive gene sequence based markers, but unfortunately the cDNA library used for this analysis contained an unexpectedly high proportion of rRNA sequences. Nevertheless this remains a sensible objective, and would also permit the alignment of these maps with that recently presented for D. tokoro (Terauchi and Kahl, 1999). Both maps provide useful tools for further genetic analysis of agronomically important traits in yam. While AFLPs continue to be identified and used for mapping the yam genome, efforts are geared towards saturating the map with microsatellites (SSRs) and ESTs, for greater ease of application in yam breeding.

\section{Identification of candidate genes}

Selective genotyping is a very effective approach for initial QTL analysis in plants (Van Gestel et al., 2000). Because of the large families that can be generated for genetic analysis and the clonal status of each genotype of the segregating population, selective pressure can be applied in phenotypic evaluations following which extremes of phenotype are selected for genotyping. For example, selective genotyping coupled with DNA sample pooling has been shown to be very efficient for initial identification of disease resistance-linked markers. The approach has been successfully applied in yams for identification of YMV and anthracnose resistance genes (Mignouna et al., 2002 a, b). Two RAPD markers OPW $18_{850}$ and OPX $15_{850}$ closely linked in coupling phase with the dominant YMV-resistance locus $Y m v$-1 were identified. These markers successfully identified the resistance gene in resistant genotypes among a sample of $12 D$. rotundata varieties. Similarly, a single locus, $D c g-1$, that contributes to anthracnose resistance was identified in D. alata. Two RAPD markers, OPI17 1700 and OPE6 $_{950}$, closely linked in coupling phase with $D c g-1$ were identified. Both markers successfully identified $D c g$ 1 in resistant $D$. alata genotypes among 34 breeding lines, indicating their potential use in marker-assisted selection. The RAPD markers identified in these studies will be made more reliable, specific and easier to apply for indirect selection by converting them into co-dominant PCR-based sequence characterised amplified regions (SCARs). Further AFLP mapping is planned to identify additional QTLs and strengthen existing marker-QTL linkages. Candidate gene analyses are yet to be employed to investigate a variety of traits. To date, 
significant associations have been demonstrated for disease resistance in many crops, including tomato and potato. The Yam breeding program at IITA is initiating the use of marker-assisted selection (MAS) for choosing parental lines for breeding purposes. It is likely that as QTL experiments are expanded, additional genes will be identified for use in breeding.

Initial QTL studies indicated that the pyramiding of major resistance genes may be a valuable strategy for YMV and anthracnose resistance breeding (Mignouna et al., 2002a, b). This strategy is appropriate if the pathogen is exclusively asexual/clonal and if the potential for gene flow is low. But if the pathogen is recombining then the recombination of virulence alleles may occur as quickly as breeders can recombine resistance genes, thus frustrating breeding efforts (McDonald and Linde, 2002). This appears to be the case with $C$. gloeosporioides whose sexual stage Glomerella cingulata is present in yam fields (Abang, 2003), and field populations have been shown to exhibit extremely high genotypic diversity (Thottappilly et al., 1999; Abang, 2003). If the sexual stage plays an important role in yam anthracnose epidemics, then yam breeders will have to consider laying emphasis on race nonspecific resistance and increased diversity in host populations (McDonald and Linde, 2002).

\section{CURRENT DEVELOPMENTS IN YAM GENOME ANALYSIS}

\section{Development of genomic resources}

The development of genomic resources and technology is a major focus in the yam genetics and breeding community. To date, one genomic DNA library has been developed (unpublished data). A cDNA library has been produced from male flowers. The library was constructed in Bluescript vector and used for EST analysis because this approach has proven to be the most efficient for gene identification, gene expression profiling and cataloguing. It also provides markers and resources for the development of cDNA microarrays. Microarrays are not yet available for yams, mainly because the number of available genes is still very small.

Another reliable and potentially powerful way of identifying candidate loci controlling agronomic traits in yam is by the application of the cDNA/AFLP technique, which generates polymorphic transcript derived fragments (TDFs) between the parents of a mapping cross. Once candidate genes have been identified, they can be employed in gene tagging and QTL mapping studies to look for associations between the candidate gene and the trait in question. The availability of a BAC library and the development of an effective system for transforming yam with large DNA fragments will provide conclusive evidence of the contribution of the candidate gene, through complementation studies.

\section{Development of ESTs from cDNA}

The genome size of tetraploid $D$. rotundata was estimated by Feulgen-stained root tip nuclei to be $0.8 \mathrm{pg}$ per haploid nucleus, and thus is equivalent to the genome size of species such as rice, soybean and spinach (Conlan et al., 1995). The current $D$. rotundata map covered a minimum of $56 \%$ of the yam genome. Considering the haploid nuclear DNA content of $D$. rotundata to be $800 \mathrm{Mbp} / 1 \mathrm{C}$ the physical distance per map unit could be estimated at $400 \mathrm{~kb}$ per $\mathrm{cM}$, making map-based gene cloning feasible (Mignouna et al., 2002e). We have generated ESTs from cDNA clones randomly picked from libraries constructed from male flowers. This project, sponsored by Gatsby Charitable Foundation, has led to the sequencing and initial analysis of 1100 ESTs. Unfortunately, most of the sequenced ESTs were either ribosomal or housekeeping genes. It will be useful to pursue this initiative in order to identify more useful genes for genomic studies. The data obtained by sequencing additional ESTs will be helpful in comparative mapping efforts with other root and tuber crops, candidate gene discovery, and gene expression analysis.

\section{Development of a microarray system for functional analysis}

To understand the physiological complexity of the yam genome, expression and/or functional gene analyses need to be undertaken. Northern analysis and differential display PCR techniques can be used, but these techniques have limitations as to the number of genes that can be analyzed simultaneously. There is a need to develop/consider approaches such as the use of cDNA on microarrays. Other plant microarrays could be tested and used. As pointed out earlier, the development of a large number of ESTs will allow larger scale expression analysis.

\section{CONCLUDING REMARKS}

With the development of new genotypes of yam through hybridization by IITA scientists, new materials are being made available both in seed and tissue culture form to a number of African countries. Requests have been received from Rwanda, Guinea Conakry, Gambia, Guinea Bissau, Kenya, Equatorial Guinea, as well as from Cuba, Japan and Korea. Other countries that have shown interest include Sudan, Uganda, and Malawi. It is 
hoped that in the near future yam cultivation will expand and become popular in other African countries, particularly in East and Central Africa. Molecular markers should make yam breeding more efficient, and thus reduce the cost and time required to produce new varieties.

Understanding and exploiting the complexity of the yam genome for improved yield and quality of yams remains a huge challenge. Large-scale gene identification and mapping have taken place in a number of model plants (e.g. Arabidopsis and Medicago) as well as some important food crops (e.g. rice, soybean, tomato and maize). Whole genome sequencing and expression analyses have been conducted in Arabidopsis and rice, and offer opportunities to understand the biological complexity of other plant genomes. However, these advances are yet to benefit under-researched food crops such as yams.

Efforts in yam genetics and genomics should be pursued and we believe the following specific areas need to be addressed in the near future. First, genetic linkage mapping of both species should be continued. A consensus and denser genetic map for both species must be constructed for practical breeding and germplasm enhancement purposes. QTL mapping should be reactivated with the initial identification of markers linked to disease resistance genes; more QTL markers should be sought. Candidate gene identification using microarray and other approaches should be conducted in order to pin down the genes (QTLs) involved in important agronomic traits. BAC library construction should be initiated, and efforts towards establishing a system for yam transformation should now be given more impetus (Tor et al., 1998). Embryo rescue will enable yam breeders to successfully make wide crosses with a greater number of related species of wild yams and have access to a much wider range of genes that can be used for the genetic improvement of yams. Wide crosses and embryo culture hold great promise for the transfer of tolerance to biotic and abiotic stresses from wild relatives to cultivated yams. Research to better understand the biology and agronomy of wild relatives will greatly facilitate efforts aimed at unlocking the genetic potential hidden in the wild yam germplasm.

\section{ACKNOWLEDGEMENTS}

The authors would like to acknowledge the financial support from Gatsby Charitable Foundation, UK through funds to support yam genome analysis at IITA. We thank Prof. Stephen Kresovich, and the staff of the Institute for Genomic Diversity of Cornell University, for their technical assistance in developing genomics tools for yam genome analysis.

\section{REFERENCES}

Abang MM (2003). Genetic diversity of Colletotrichum gloeosporioides Penz. causing anthracnose disease of yam (Dioscorea spp.) in Nigeria. Bibliotheca Mycologica Vol 197. J. Cramer Science Publishers Berlin, Stuttgart.

Abang MM, Winter S, Green KR, Hoffmann P, Mignouna HD, Wolf GA (2002). Molecular identification of Colletotrichum gloeosporioides causing anthracnose of yam in Nigeria. Plant Pathol. 51:63-71.

Asemota HN, Wellington M, Odutuga AA, Ahmad MH (1992). Effect of short-term storage on phenolic content, o-diphenolase and peroxidase activities of cut yam tubers (Dioscorea spp.). J. Sci. Food Agric. 60: 309-312.

Asemota HN, Ramser J, Lopez-Peralta C, Weising K, Kahl G (1996). Genetic variation and cultivar identification of Jamaican yam germplasm by random amplified polymorphic DNA analysis. Euphytica 92:341-351.

Asiedu R, Ng SYC, Bai KV, Ekanayake IJ, Wanyera NMW (1998). Genetic Improvement. In Orkwor GC, Asiedu R, Ekanayake IJ (eds) Food yams: Advances in research, Ibadan, Nigeria: IITA and NRCRI, pp 63-104.

Barrau J (1965). Histoire et prehistoire horticole de l'Oceanie tropicale. J. Soc. Oceaniste 21:55-78.

Conlan SR, Griffiths LA, Napier JA, Shewry PR, Mantell S, Ainsworth C (1995). Isolation and characterization of cDNA clones representing the genes encoding the major tuber storage protein (dioscorin) of yam (Dioscorea cayenensis Lam.). Plant Mol. Biol. 28:369-380.

Dansi A, Mignouna HD, Zoundjihékpon J, Sangaré A, Asiedu R, Ahoussou N (2000a). Using isozyme polymorphism to assess genetic variation within cultivated yams (Dioscorea cayenensis/Dioscorea rotundata complex) of the Benin Republic. Genet. Resourc. Crop Evol. 47:371-383.

Dansi A, Mignouna HD, Zoudjihekpon J, Sangare A, Asiedu R, Ahoussou N. (2000b). Identification of some Benin Republic's Guinea yam (Dioscorea cayenensis/Dioscorea rotundata) cultivars using randomly amplified polymorphic DNA. Genet. Resourc. Crop Evol. 47: 619-625.

Dansi A, Mignouna HD, Zoundjihekpon J, Sangare A, Asiedu R, Quin FM (1999). Morphological diversity, cultivar groups and possible descent in the cultivated yams (Dioscorea cayenensis-D. rotundata complex) of Benin Republic. Genet. Resourc. Crop Evol. 46: $371-$ 388

Dansi A, Mignouna HD, Zoundjihékpon J, Sangaré A, Asiedu R, Quin FM (1998). Varietal identification key of the cultivated yams (Dioscorea cayenensis-D. rotundata complex) of Benin Republic. Plant Genet. Resourc. Newsl. 116:18-25.

FAO (2002). FAOSTAT Agriculture data. Food and Agriculture Organisation of the United Nations. http://apps.fao.org/collections

Green KR (1998). Distribution and severity of foliar diseases of yam (Dioscorea spp.) in Nigeria. In: Proceedings of the 6th Triennial Symposium of ISTRC-AB, Lilongwe, Malawi, 22-28 Oct. 1995. ISTRC-AB/Gov't of Malawi/IITA, Ibadan, Nigeria. pp 439-444.

Ikediobi CO, Igboanusi LC (1983). Identification of yam, Dioscorea spp. cultivars by use of electrophoretic patterns of soluble tuber proteins. Biotropica 15:65-67.

McDonald BA, Linde C (2002). Pathogen population genetics, evolutionary potential, and durable resistance. Annu. Rev. Phytopathol. 40:349-379.

McDonald FD, Alleyne AT, Ogarro LW, Delauney AJ (1998). Yam anthracnose in the English-speaking islands of the Eastern Caribbean-successes and research advances in disease management. Trop. Agric. 75:53-57.

Mignouna HD, Dansi A, Zok S (2002c). Morphological and isozymic diversity of the cultivated yams (Dioscorea cayenensis/Dioscorea rotundata complex) of Cameroon. Genet. Resourc. Crop Evol. 49:2129.

Mignouna HD, Mank RA, Ellis THN, van den Bosch N, Asiedu R, Abang MM, Peleman J (2002d). A genetic linkage map of water yam (Dioscorea alata L.) based on AFLP markers and QTL analysis for 
anthracnose resistance. Theor. Appl. Genet. 105:726-735

Mignouna HD, Mank RA, Ellis THN, van den Bosch N, Asiedu R, Ng SYC, Peleman J (2002e). A genetic linkage map of Guinea yam (Dioscorea rotundata L.) based on AFLP markers. Theor. Appl. Genet. 105:716-725.

Mignouna HD, Dansi A (2003). Yam (Dioscorea spp) domestication by the Nago and Fon ethnic groups in Benin. Genet. Resourc. Crop Evol. 50:519-528.

Mignouna HD, Asiedu R (1999). A genetic linkage map of Guinea yam (Dioscorea rotundata Poir) based on isozyme, RAPD and AFLP markers. Abstract P287 PAG VII, San Diego CA. http://www.intlpag.org

Mignouna HD, Abang MM, Onasanya A, Asiedu R (2002a). Identification and application of RAPD markers for anthracnose resistance in water yam (Dioscorea alata). Ann. Appl. Biol. 141:6166.

Mignouna HD, Abang MM, Onasanya A, Agindotan B, Asiedu R (2002b). Identification and potential use of RAPD markers linked to Yam mosaic virus resistance in white yam (Dioscorea rotundata Poir.). Ann. Appl. Biol. 140:163-169.

Mignouna HD, Abang MM, Green KR, Asiedu R (2001a). Inheritance of resistance in water yam (Dioscorea alata) to anthracnose (Colletotrichum gloeosporioides). Theor. Appl. Genet. 103:52-55.

Mignouna HD, Abang MM, Fagbemi SA (2003). A comparative assessment of molecular marker assays (AFLP, RAPD and SSR) for white yam (Dioscorea rotundata Poir.) germplasm characterisation. Ann. Appl. Biol. 142:269-276.

Mignouna H.D, Ellis NTH, Asiedu R, Ng QN (1998). Analysis of genetic diversity in Guinea yams (Dioscorea spp) using AFLP fingerprinting. Trop. Agric. (Trinidad) 75:224-229.
Mignouna HD, Njukeng P, Abang MM, Asiedu R (2001b). Inheritance of resistance to Yam Mosaic Virus, genus Potyvirus, in white yam (Dioscorea rotundata). Theor. Appl. Genet. 103:1196-1200.

$\mathrm{Ng}$ SYC (1992). Micropropagation of white yam (Dioscorea rotundata Poir.). In: Biotechnology in Agriculture and Forestry, High-tech and Micropropagation III, Vol. 19 (Ed. Bajai, V.P.S.). Springer-Verlag Berlin, Heidelberg, pp. 135-159.

Solomon-Blackburn RM, Barker H (2001). Breeding virus resistant potatoes (Solanum tuberosum): a review of traditional and molecular approaches. Heredity 86:17-35.

Terauchi R, Kahl G (1999). Mapping of the Dioscorea tokoro genome: AFLP markers linked to sex: Genome 42:752-762.

Thottappilly G, HD Mignouna, Onasanya A, Abang M, Oyelakin O, Singh NK (1999). Identification and differentiation of isolates of Colletotrichum gloeosporioides from yam by random amplified polymorphic DNA markers. African Crop Sci. J. 7:195-205.

Thouvenel, J.C. and R. Dumont. 1990. Perte de rendement de l'igname infectée par le virus de la mosaique en Cote d'Ivoire. L'Agron. Trop. 45: 125-129.

Tor M, Twyford CT, Funes I, Boccon-Gibod J, Ainsworth CC, Mantell $\mathrm{SH}$ (1998). Isolation and culture of protoplasts from immature leaves and embryogenic cell suspensions of Dioscorea yams: tools for transient gene expression studies. Plant Cell Organ Tissue Cult. 53:113-126.

Van Gestel S, Houwing-Duistermaat JJ, Adolfsson R, van Duijn CM, Van Broeckhoven C (2000). Power of selective genotyping in genetic association analyses of quantitative traits. Behav. Genet. 30:141-146.

Winch JE, Newhook FJ, Jackson GVH, Cole JS (1984). Studies of Colletotrichum gloeosporioides disease on yam, Dioscorea alata, in Solomon Islands. Plant Pathol. 33:467-477. 